\title{
Variation of Some Physico-Chemical Parameters and Biodiversity of Gastropods Species in Euphrates River, Iraq
}

\author{
Jasim Mohammed Salman and Ahmed Joudah Nassar
}

\begin{abstract}
The biodiversity of some Gastropods taxa were studied in three selected stations in Euphrates River middle of Iraq (Musayb; Saddat Al-hindya and Hindya city) from October 2011 to September 2012.Some Physico-chemical parameters( air \&water temperature; pH; TDS; TSS; DO;BOD5; Total harhness) of water in this stations were estimated which have been calculated some biodiversity indices of the of Gastropods species in the study area. Five species of gastropods were recorded, and their density was varied significantly $(p<0.01, p<0.05)$ among stations and months of study, so they showed positive and negative Correlations with physico-chemical parameters of the study area.
\end{abstract}

Index Terms-Biodiversity, Gastropod, Physic-chemical parameters, Euphrates River, Iraq.

\section{INTRODUCTION}

Essentially, biodiversity reflects the ecological quality of the habitats, freshwater biodiversity constitutes the important component of the planet, with the species richness that are relatively high when it was compared with both terrestrial and marine ecosystems [1]. The mollusks is an extraordinarily various phylum with 80,000-100,000 described species and total diversity as high as 200,000, there are only two arthropods in the species richness. Freshwater Gastropods are founded in every continent except Antarctica and innearly all aquatic habitats including rivers, lakes, streams, swamps, underground aquifers and springs, as well as temporary ponds, drainage ditches and other ephemeral and seasonal waters. Most of live submerged are specialized to particular habitats aquatic vegetation, stones, rocks, wood and other solid surfaces, or soft sediment [2]. Most of freshwater Gastropods are microherbivorous and/or micro-omnivorous grazers feeding on bacterial films, algae and diatoms [3].

The environmental parameters that are affecting the distribution of aquatic mollusks are not well understood, however, it is generally accepted that the distribution of freshwater mollusks varies with physical, chemical, and biological characteristics aquatic system [4]. Natural populations of freshwater gastropods are subjected to severe ecological constraints imposed by large temporal fluctuations of their environment; their success is depending on their physiological capacity to tolerate these fluctuations [5]. Gastropods usually play a dominant role in the ecology

\footnotetext{
Manuscript received October 9, 2013; revised December 11, 2013.

Jasim Mohammed Salman is with Environmental Research Center, Coll. of Science, University of Babylon, Iraq (email:jasimsalman67@yahoo.com).
}

of fresh-waters by providing food for many animals and by grazing on vast amounts of algae and detritus [6]. The aim of this study is the assessment of the environment and the biodiversity of fresh water gastropods, detection the abundant species and less abundant species in Euphrates River in middle of Iraq.

\section{MATERIALS AND METHODS}

\section{A. Study Area}

Samples were collected monthly from three sites (AlMusayab district; Saddat Al -Hndiaa city and Al-Hindiaa District ) on Euphrates River / middle of Iraq Fig. 1, from October 2011 to September 2012 in order to measure the Physico-chemical parameters of water using clean polyethylene bottle (5L) as three replicates while Gastropods individuals were obtained by hand collection from hard substrata in shallow waters ; stones and rocks or from the net of the fishermen or from aquatic plants in the near shore. Soft substratum and plant material on Gastropods were removed by washing with the river water, and then putting in plastic bag and when they were brought to the laboratory, they would have been washed with tap water and distilled water in order to remove any residue, The Gastropods species classified according to Ahmed [7] and stored in clean bags under freezing.

\section{B. Physico-Chemical Parameters}

Air and water temperature was measured directly using graduated thermometer $\left(0 \mathrm{C}^{\circ}-100 \mathrm{C}^{\circ}\right)$.Total dissolved solids (TDS) Measured by electrical conductivity meter type WTW Germany. The total suspended solids (TSS) were measured depending on procedure that has been described by APHA [8]. PH was measured by $\mathrm{pH}$ meter type Hanna com. after calibration by standard solutions. Dissolved oxygen meter (Oakton) U.S manufacturing was used to determine the concentration of dissolved oxygen (DO) $(\mathrm{Mg} / \mathrm{L}) \%)$. While BOD5 was calculated after incubation at $20 \pm$ for 5 days. Total hardness was determined according to [9].

\section{Ecological Indices}

The relative abundance index (Ra), was calculated according to Omori and Ikeda equation [10]. Constancy index (S).The presences and replication of all individuals were calculated according to [11]. The species richness index (D*) was collocated monthly according to [12]. Shanon-Weiner diversity index $(\mathrm{H})$ was calculated using Shanon-Weiner equation according to [13]. Sorensen 
similarity index (Cs) was calculated monthly according to [14].

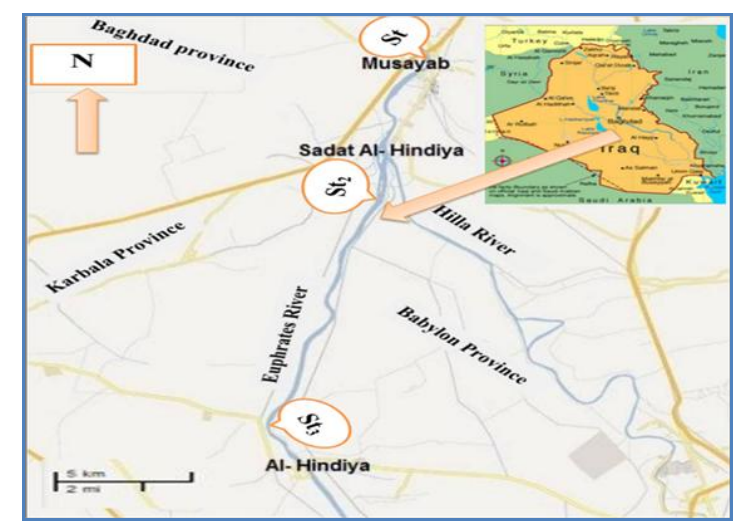

Fig. 1. Satellite image of study sites location on Euphrates River.

\section{RESULT AND DISCUSSION}

\section{A. Abiotic Factors}

The physico-chemical parameters of the stations were given in (Table I). Air temperature was ranged between the highest values during July $\left(43.5^{\circ} \mathrm{C}\right)$ in St.3 and the lowest values during February $\left(9^{\circ} \mathrm{C}\right)$ in St.2. The highest water temperature values were observed during July $\left(31.43^{\circ} \mathrm{C}\right)$ in St.3 and the lowest values were observed during January $\left(9.06{ }^{\circ} \mathrm{C}\right)$ in St.2 .The results were showed significant deference $(p<0.01, p<0.05)$ between months and show positive and negative correlation between temperature and other parameters. The present study was showed obvious change in air and water temperature during the seasons, while the highest values of temperature were recorded during summer and the lowest were recorded during winter, this variation was occurred because the seasonal and geographical change and the difference in time of sampling This result have been agreed with what was reported by [15], [16].

The highest $\mathrm{pH}$ values were recorded during march (8.74) in St.3 and the lowest values were recorded during august (7.54) in St.2. The results were showed significant deference $(p<0.01, p<0.05)$ between months and revealed positive and negative correlation between $\mathrm{pH}$ and other parameters. The $\mathrm{pH}$ was showed slightly alkaline trend. Generally $\mathrm{pH}$ of water would have been influenced by geological of catchments area and buffering capacity of water [17]. This agrees with that reported by [18], [19].

The results were revealed significant deference $(p<0.01$, $p<0.05$ ) in values of total dissolved solid (TDS)between months and the sites were ranged from the highest value during February $(789.3 \mathrm{mg} / \mathrm{L})$ in St.3 to the lowest value during January $(502.33 \mathrm{mg} / \mathrm{L})$ in St.2.Positives and negative correlations were observed between TDS and some parameters. Total Suspended Solid (TSS) were fluctuated between the lowest values during February $(0.006 \mathrm{mg} / \mathrm{L})$ in St. 2 and the highest values during October $(0.0443 \mathrm{mg} / \mathrm{L})$ in St.1. The results were showed negative correlations between (TSS) and some parameters and significant deference $(p<0.01, \quad p<0.05)$ between months. The distribution of TDS and TSS are relatively increased during drought period due to the decay and degradation of the most microorganism species in the lower water level [20]. The present values of TDS and TSS in Table I were founded in the same ranges that recorded by Al-yasari [19] during winter in the same area.

TABLE I: PHYSICO-CHEMICAL PARAMETERS OF WATER IN STUDY SiTES FROM OCTOBER 2011 TO SEPTEMBER 2012 IN EUPHRATES RIVER. (RANGE =

\begin{tabular}{|c|c|c|c|}
\hline \multirow{2}{*}{ Parameters } & \multicolumn{3}{|c|}{ Sites } \\
\hline & 1 & 2 & 3 \\
\hline $\begin{array}{l}\text { Air } \\
\text { Temperature }\end{array}$ & $\begin{array}{l}11.72-39.27 \\
22.27 \pm 7.76\end{array}$ & $\begin{array}{l}9-38.2 \\
23 \pm 9.34\end{array}$ & $\begin{array}{l}13.33-43.5 \\
26.53 \pm 8.86\end{array}$ \\
\hline $\begin{array}{l}\text { Water } \\
\text { Temperature }\end{array}$ & $\begin{array}{l}11.54-30.37 \\
19.73 \pm 6.69\end{array}$ & $\begin{array}{l}9.06-29.96 \\
20.08 \pm 6.85\end{array}$ & $\begin{array}{l}13.03-31.43 \\
21.09 \pm 6.23\end{array}$ \\
\hline p H & $\begin{array}{l}7.66-8.71 \\
8.26 \pm 0.34\end{array}$ & $\begin{array}{l}8.7-7.54 \\
8.18 \pm 057\end{array}$ & $\begin{array}{l}7.6-8.74 \\
8.29 \pm 0.34\end{array}$ \\
\hline $\begin{array}{l}\text { Total } \\
\text { Dissolved solid } \\
(\mathrm{Mg} / \mathrm{L})\end{array}$ & $\begin{array}{l}540.22-758.44 \\
641.1 \pm 68.71\end{array}$ & $\begin{array}{l}502.33-739 \\
624 \pm 64.81\end{array}$ & $\begin{array}{l}572-789.3 \\
651 \pm 76\end{array}$ \\
\hline $\begin{array}{l}\text { Total } \\
\text { Suspended } \\
\text { solid }(\mathrm{Mg} / \mathrm{L}) \\
\end{array}$ & $\begin{array}{l}0.0104-0.0443 \\
0.0226 \pm 0.0209\end{array}$ & $\begin{array}{l}0.006-0.0323 \\
0.0172 \pm 0.0069\end{array}$ & $\begin{array}{l}0.063-0.031 \\
0.0176 \pm 0.00754\end{array}$ \\
\hline $\begin{array}{l}\text { Dissolved } \\
\text { Oxygen } \\
(\mathrm{Mg} / \mathrm{L}) \\
\end{array}$ & $\begin{array}{l}6.9-11.38 \\
8.69 \pm 1.4\end{array}$ & $\begin{array}{l}6.27-11.59 \\
8.96 \pm 1.52\end{array}$ & $\begin{array}{l}6.63-10.78 \\
8.44 \pm 1.3\end{array}$ \\
\hline $\begin{array}{l}\text { Biological } \\
\text { Oxygen } \\
\text { Demand( } \\
\mathrm{Mg} / \mathrm{L}) \\
\end{array}$ & $\begin{array}{l}1.28-4.216 \\
2.33 \pm 1.1\end{array}$ & $\begin{array}{l}0.94-4.04 \\
2.9 \pm 1\end{array}$ & $\begin{array}{l}1.05-3.86 \\
2.25 \pm 0.94\end{array}$ \\
\hline $\begin{array}{l}\text { Total hardness } \\
\left(\mathrm{Mg} \mathrm{CaCO}_{3} / \mathrm{L}\right)\end{array}$ & $\begin{array}{l}446.33-749.44 \\
548.9 \pm 96.55 \\
\end{array}$ & $\begin{array}{l}446.6-700 \\
529.6 \pm 81.23 \\
\end{array}$ & $\begin{array}{l}423.33-773.3 \\
550 \pm 101.3 \\
\end{array}$ \\
\hline
\end{tabular}

The dissolved oxygen (DO) values were ranged the between lowest values during September $(6.63 \mathrm{mg} / \mathrm{L})$ in St. 3 and the highest values during Novembers $(11.59 \mathrm{mg} / \mathrm{L})$ in St.2. The results show significant deference $(p<0.01$, $p<0.05)$ between months positive and negative correlation between DO and some parameters. The results which were obtained from this study were showed an elevated DO during winter and a decrease during summer, this was expected since the solubility of gasses in liquids is inversely proportional with temperature [21], The results were showed negative correlation between DO; water and air temperature and $\mathrm{pH}$. This was agreed with what was reported by Al-Saffar [22]. Biological oxygen demand $\left(\mathrm{BOD}_{5}\right)$ values were fluctuated between the lowest values during December (0.94 mg / L) in St.1 and the highest during October $(4.21 \mathrm{mg} / \mathrm{L})$ in St.2. The results show significant deference $(p<0.01, p<0.05)$ in values of $\mathrm{BOD}_{5}$ between months and sites, and also show positive and negative correlation between $\mathrm{BOD}_{5}$ and some parameters. The results were showed $\mathrm{BOD}_{5}$ values within the normal range of (WHO). This was agreed with which was presented by $\mathrm{Al}$ - Ghanemi [18].

Total hardness (TH) was founded to be at the range between the lowest values during January $(423.3 \mathrm{mg} / \mathrm{L})$ in St. 2 and the highest during march $(773.3 \mathrm{mg} / \mathrm{L})$ in St. 3 .The results show significant deference $(\mathrm{p}<0.01, \mathrm{p}<0.05)$ between months and negative correlation between $\mathrm{TH}$ and $\mathrm{BOD}_{5}$ .The $\mathrm{TH}$ was considered to be a good indicator for the presence of some dissolved solid substance in water such as the $\mathrm{Ca}^{2+}$ and $\mathrm{Mg}^{2+}$ [23]. 


\section{B. Biotic Factors}

The total density of Gastropods species and the number of appearance of all species during the time of study were explained in (Table II, Fig. 2), the result show the highest density values in St.3 and lowest in St.2 (Fig. 2). Table III shows the abundance of each gastropod species in the sites according to the relative abundance index (Ra) the species Viviparus bengalensis was showed relative high abundance comparing with other species. The results were showed significant deference $(p<0.01, p<0.05)$ between months and Correlation between the abundance gastropod species and physico-chemical parameters of the study area that were presented.

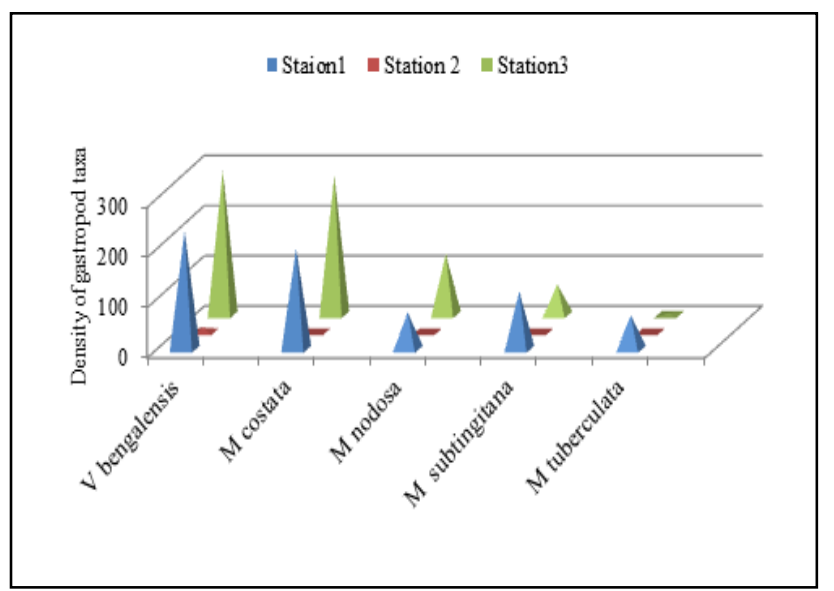

Fig. 2. Total density of gastropod species of gastropod species in study sites from October 2011 to September 2012 in Euphrates river.

TABLE II: THE TOTAL DENSITY (FIRST LINE) AND NUMBER OF APPEARANCE (SECOND LINE) OF GASTROPOD SPECIES IN STUDY SITES FROM OCTOBER 2011 TO SEPTEMBER 2012 IN EUPHRATES RIVER

\begin{tabular}{|l|c|c|c|}
\hline \multirow{2}{*}{\multicolumn{1}{c|}{ Species }} & \multicolumn{3}{|c|}{ Sites } \\
\cline { 2 - 4 } & 1 & 2 & 3 \\
\hline Viviparus bengalensis & 236 & 9 & 287 \\
& 9 & 4 & 12 \\
\hline Melanopsis costata & 202 & ----- & 277 \\
& 12 & & 11 \\
\hline Melanopsis nodosa & 74 & ----- & 121 \\
& 9 & & 11 \\
\hline Melanopsis subtingitana & 116 & ---- & 60 \\
& 12 & & 8 \\
\hline Melanoides tuberculata & 68 & ---- & 4 \\
& 7 & & 2 \\
\hline Total & 622 & 9 & 749 \\
& & & \\
\hline
\end{tabular}

TABLE III: RELATIVE ABUNDANCE INDEX (RA) OF GASTROPOD SPECIES IN STUDY SITES FROM OCTOBER 2011 TO SEPTEMBER 2012 IN EUPHRATES

\begin{tabular}{|c|c|c|c|}
\hline \multicolumn{4}{|c|}{ RIVER } \\
\hline \multirow{2}{*}{ Species } & \multicolumn{3}{|c|}{ Sites } \\
\hline & 1 & 2 & 3 \\
\hline Viviparus bengalensis & $* *$ & $*$ & $* *$ \\
\hline Melanopsis costata & $* *$ & $\because$ & $* *$ \\
\hline Melanopsis nodosa & $* *$ & - & $*$ \\
\hline Melanopsis subtingitana & $* *$ & - & $*$ \\
\hline Melanoide stuberculata & $*$ & - & $*$ \\
\hline
\end{tabular}

Table IV shows the Constancy of species according to
Constancy index $(\mathrm{S})$. The results were showed that the most of species are constant in St.1 and St. 3 while there were no constancy showed in St. 2 in the present study.

TABLE IV: CONSTANCY INDEX (S) OF GASTROPOD SPECIES IN STUDY SITES FROM OCTOBER 2011 TO SEPTEMBER 2012 IN EUPHRATES RIVER

\begin{tabular}{|l|c|c|c|}
\hline \multirow{2}{*}{\multicolumn{1}{|c|}{ Species }} & \multicolumn{3}{|c|}{ Sites } \\
\cline { 2 - 4 } & 1 & 2 & 3 \\
\hline Viviparus bengalensis & 75 & 33.3 & 100 \\
\hline Melanopsis costata & 100 & -- & 91.6 \\
\hline $\begin{array}{l}\text { Melanopsis } \\
\text { subtingitana }\end{array}$ & 100 & -- & 66.6 \\
\hline Melanopsis nodosa & 75 & -- & 91.6 \\
\hline Melanoide stuberculata & 58.3 & -- & 16.6 \\
\hline
\end{tabular}

$50 \%<$ Constant Species. 25\%-50\% Accidental Species. 1\%-20\% Accessory Species

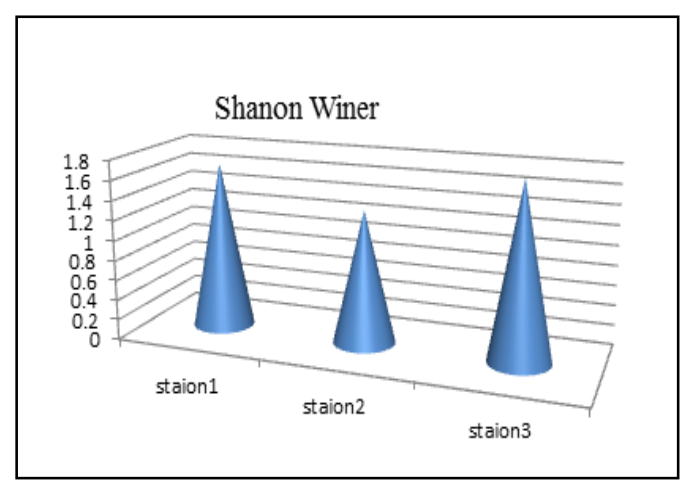

Fig. 3. Shanon-winer index of gastropod species in study sites from October 2011 to September 2012 in Euphrates river.

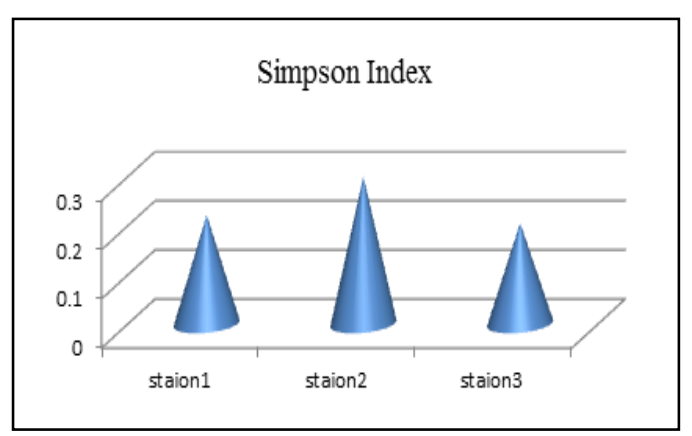

Fig. 4. Simpson index of gastropod species in study sites from October 2011 to September 2012 in Euphrates river.

According to the Shannon-Wiener index, Fig. 3, the species diversity in Euphrates River in middle of Iraq was founded to be 1.59 at average. The highest level of diversity was founded at St.3 (1.76) and its lowest was founded at St.2 (1.332).Simpson diversity Index (D) the result were showed the value of this index ranging between the highest values (0.222) in St.2 and lowest values (0.205) in St.3, Fig. 4 , the values of this index were increased the with decrease of the diversity (show negative correlation with the diversity).This was agreed with that of [24].

According to Sorensen similarity index, St.1 and St.3 were founded to be the completely similar and St.2 was the most dissimilar to each other sites in the gastropod diversity .The result were showed lowest diversity values in St.2 that was probably occurred due to the location of St.2 which was near Al- Hindyia barrage. It is obviously seen that the groups of gastropods are different with the study sites, this may have been related to the changes in the environment, to the industrial or organic pollution [25]. Benthic macro invertebrates are susceptible to the local environmental perturbation, which are also effective integrators of the 
environmental contamination, this means, they were responded to all contaminants in the environment not only those were measured in conventional water or sediment quality monitoring program [26].

\section{CONCLUSION}

- Spatial and temporal variation on Physical and chemical factors of Euphrates river.

- Midrate diversity of Gastropod species through period and study sites.

- Clear relationship between ecological properties and diversity of aquatic organisms under study.

\section{ACKNOWLEDGEMENT}

The authors acknowledge the Biology Department, College of Sciences in University of Babylon, Iraq for provisions of facilities to complete this work.

\section{REFERENCES}

[1] D. C. Allen and C. C. Vaughn, "Density-dependent biodiversity effects on physical habitat modification by freshwater bivalves," Ecology, vol. 92, no. 5, pp. 1013-1019, 2011.

[2] E. Strong, O. Gargominy, W. Ponder, and P. Bouchet, "Global diversity of gastropods (Gastropoda; Mollusca) in freshwater," Hydrobiologia, vol. 595, pp.149-166, 2008.

[3] T. Sitnikova, E. Soldatenko, R. Kamaltynov, and F. Riedel, "The finding of North American freshwater gastropods of the genus Planorbella Haldeman, 1842 (Pulmonata: Planorbidae) in East Siberia," Aquatic Invasions, vol. 5, no. 2, pp. 201-205.

[4] S. Sharpe, "Solute Composition: A Parameter Affecting the Distribution of Freshwater Gastropods," in Proc. Conference Springfed Wetlands: Important Scientific and Cultural Resources of the Intermountain Region, 2002.

[5] H. M. Kalyoncu, "Species composition of mollusca in the Aksu river system (Turkey) in relation to water quality," Fresenius Environmental Bulletin, vol. 18, no. 8, pp. 1446-1451, 2009.

[6] A. I. Agudo-Padrón, "Current knowledge on population studies on five continental mollusks (Mollusca, Gastropoda et Bivalvia) of Santa Catarina State (SC, Central Southern Brazil region)," Biodiversity Journal, vol. 2, no. 1, pp. 9-12, 2011.

[7] M. M. Ahmed, "Systematic study on Mollusca from Arabian Gulf and Shatt Al-Arab, Center for Arab Gulf studies," University of Basrah, Iraq, 1975, pp. 75.

[8] A. P. H. A. (American Public Health Association), Standard Methods for Examination of Water and Wastewater, $20^{\text {th }} \mathrm{Ed}$ Washington DC, USA, 2003.

[9] O. T. Lind, Handbook of Common Method in Limnology, C. V. Mosby Co., ST. Louis, 1979, pp. 199.

[10] M. Omori and T. Ikeda, Methods in Marine Zooplankton Ecology, Wiley and Sons, New York, 1984.

[11] M. Serafim, F. A. Lansac-Toha, J. C. Paggi, F. M. Velho, and B. Robertson, "Cladocera fauna composition in a river floodplain, with a new record for Brazil," Brazil. J. Biol., vol. 63, no. 2, pp. 349-356, 2003.

[12] F. H. Sklar, "Seasonality and community structure of the Back swamp invertebrates in Alonisiana Tupelo wetlands," Wetland J., vol. 5, pp. 69-86, 1985.

[13] A. Mangurran, Ecological Diversity and Its Measurement, Great Britain, 1988.
[14] S. B. Hamayoun, B. Nasreen, and T. C. James, "Depth distribution of microbial diversity in Mono Lake, a meromectic soda lake in California," Appl. and Environ. Microbiol., vol. 69, no. 2, pp. 10301042, 2003.

[15] H. Al-Fatlawi, "Ecological study for Euphrates River between AlHindia barrage and Al-Kifil city/ Iraq," M.S. thesis, Dept. Biology, College of Science, University of Babylon, Iraq, 2005.

[16] J. M. Salman, "Environmental study of possible pollutants in Euphrates River between Hindia barrage and Al-Kufa," Ph.D. dissertation, Dept. Biology, College of Science, University of Babylon, Iraq, 2006.

[17] R. Shyamala, M. Shanthi, and P. Lalitha, "Physicochemical Analysis of Borewell Water Samples of Telungupalayam Area in Coimbatore District, Tamilnadu, India," E-Journal of Chemistry, vol. 5, no. 4 pp. 924-929, 2008.

[18] H. Al-Ghanemi, "Use Aquatic Plants as Bioindicators of Heavy Metals Pollution in Euphrates River, Iraq," M.S. thesis, Dept. Biology, College of Science, University of Babylon, Iraq, 2011.

[19] W. Al-yasari, "Ecological assessment to drinking water quality in Al-Mahaweel and Al-Hilla plants for water purification in Babylon province/Iraq," M.S. thesis, Dept Biology, Coll. Of Science, University of Babylon, Iraq, 2012.

[20] M. A. Nkansah and J. H. Ephraim, "Physicochemical Evaluation of the Water from Boreholes Selected from The EJ and BAK Districts of the Ashanti Region of Ghana," Thammasat Int. J. Sc. Tech., vol. 14, no. 3, pp. 31-40, 2009.

[21] B. Durmishi, M. Ismaili, A. Shabani, X. S. Jusufi, M. X. Fejzuli, M. Kostovska, and S. Abduli, "The physical, physical-chemical and chemical parameters determination of river water Shkumbini (Pena)," (part A). BALWOIS 2008-Ohrid, Republic of Macedonia, pp. 27-31, 2008.

[22] M. Al-Saffar, "Interaction between the Environmental Variables and Benthic Macroinvertebrates Community Structure in Abu Zirig Marsh, Southern Iraq,” M.S. thesis, College of Science, University of Baghdad, Iraq, 2006

[23] W. A. Wurts and R. M. Durborow, Interaction of PH, Carbon Dioxide, Alkalinity and Hardness in Fish Ponds, Southern Regional Aquaculture Center of Kentucky State University, USA, 1992, vol 464 , no. 2-5.

[24] R. Al-Nemrawi, "A study of biodiversity of zooplankton and benthic macroinvertebrate in Tigris and Euphrates River in middle Iraq," $\mathrm{Ph}$. D. Thesis, Science college, University of Baghdad, Iraq, 2005.

[25] H. T. Al-Saad, W. A. Farid, A. Y. Al-Adhub, "Distribution and seasonal variations of $\mathrm{n}$-alkanes in some species of molluscs from Shatt Al-Arab river," Mesopot. J. Mar. Sci., vol. 26, no. 2, pp. 182196, 2011

[26] J. R. Karr, Biological Monitoring and Assessment in the Solution of Environmental Problems, Environmental Management, 1986.

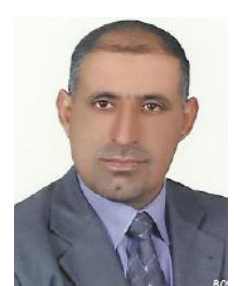

Jasim Mohammed Salman was born on January 3, 1967. He completed his Ph.D. degree in Environmental Science on Limnology \& Aquatic Biodiversity from University of Babylon, College of Science, Department of Biology, Babil, Iraq in 2006 $\mathrm{He}$ is an assistance professor of Environmental science, Faculty of Science, University of Babylon $\mathrm{He}$ served on several local and international conferences as Paper Reviewer, Expert Panel Member and Scientific Advisory. He has published more than 45 journal articles and one book in environmental science and pollution and finished 8 projects of postgraduate study .He is a member in Ecological Society of America (esa); a member of University of Babylon Conceal and the director of Environmental Research Center ,Babylon University, Iraq. 